\title{
Antimicrobial Activity of Pomegranate Peel and Its Applications on Food Preservation
}

\author{
Jing Chen, ${ }^{1}$ Chunling Liao, ${ }^{1}$ Xiaolu Ouyang, ${ }^{1}$ Ibrahim Kahramanoğlu $\mathbb{D},{ }^{2}$ Yudi Gan, \\ and Mingxi Li $\mathbb{D D}^{3}$ \\ ${ }^{1}$ Jiangxi Medical School, Nanchang 330200, China \\ ${ }^{2}$ European University of Lefke, Gemikonagi, Northern Cyprus, Mersin 10, Turkey \\ ${ }^{3}$ Research Center of Tea and Tea Culture, College of Agronomy, Jiangxi Agricultural University, Nanchang 330045, China
}

Correspondence should be addressed to Mingxi Li; li13699529617@163.com

Received 25 September 2020; Revised 18 October 2020; Accepted 23 October 2020; Published 4 November 2020

Academic Editor: Kannan R. R. Rengasamy

Copyright (c) 2020 Jing Chen et al. This is an open access article distributed under the Creative Commons Attribution License, which permits unrestricted use, distribution, and reproduction in any medium, provided the original work is properly cited.

Pomegranate (Punica granatum L.) fruit is being cultivated since the civilization is known, and its production and consumption have been increased since the last century due to the scientific confirmation of its health benefits. Pomegranate fruits, fruit juice, its seeds, and peels are known to have higher contents of bioactive compounds, viz., phenolic acids, flavonoids, and hydrolysable tannins. The peels of pomegranate fruits are the major by-products produced during food processing of pomegranate enriched in antioxidants and broad-spectrum antimicrobial agents and can prevent food deterioration even. This health potential of pomegranate is known to vary significantly upon the varieties, growing conditions, cultivation practices, stages of the development, and the extraction methods. Herein, the biochemical composition of the pomegranate peel extract (PPE), its efficacy in food preservation, and antimicrobial activities are discussed to provide a comprehensive guide for farmers, food processing, and storage sectors and academia.

\section{Introduction}

Pomegranate (Punica granatum L.) plants are among the first cultivated plants by humanity; however, its consumption had been limited most commonly as a result of the hassle of extracting the juicy arils [1]. Due to the increasing number of scientific studies about its health benefits, production and consumption of pomegranate fruits have been increasing since the beginning of the 21 st century. Pomegranate fruits are consumed as both fresh and processed mainly in the forms of juice, oil, wine, and jams. Both the fruits and its peel are known to have high levels of numerous phytochemicals, including phenolic acids, flavonoids, and tannins. This diverse characteristic of phytochemicals is thought to be responsible for its high antioxidant potential and health benefits [2]. During processing, a considerable amount of by-products are developed from peels and is known to have high contents of hydrolysable tannins (HTs) [3]. Recently, by-products of pomegranates, especially pomegranate peel extract (PPE), have been increasing attention due to its scientifically confirmed therapeutic properties such as antioxidant, antimicrobial, anticancer, antiulcer, and anti-inflammatory activities $[4,5]$. Numerous scientific studies have suggested that PPE exhibits excellent antimicrobial activity against several foodborne pathogens and improves the postharvest storability of food products $[6,7]$. This paper will describe and discuss the recent advancements about the biochemical composition, antimicrobial potential, and food preservation characteristics of PPEs.

\section{Biochemical Composition of Pomegranate Peel}

Pomegranate peels have high levels of numerous phytochemicals [2]. It has been reported that PPE is high in bioactive compounds, mainly phenolic acids, flavonoids, and hydrolysable tannins $[8,9]$. The primary phenolic acids 
identified from PPEs are ellagic acid, gallic acid, caffeic acid, chlorogenic acid, syringic acid, ferulic acid, vanillic acid, p-coumaric acid, and cinnamic acid [10-14]. Phenolic acids concentration significantly varies among varieties and is highly depending upon the geographical location, climatic conditions, and cultivation practices $[9,13]$. One of the main parameters defining the concentration of the phenolic acids was noted as the peel colour where the varieties with dark red colour reported to have higher phenolic acids concentration than the light-coloured varieties [15]. Additional to phenolic acids, PPEs are an excellent source of flavonoids. Flavonoid content and composition are also known to vary significantly among varieties and growing conditions; however, it was also noted that the fruit developmental stage influence the flavonoid content and composition $[6,16,17]$. Besides, PPEs are reported to have rich sources of tannins. The reported tannins are ellagitannins, punicalagin, granatins, punicalin, pedunculagin, castalagin, corilagin, gallagyldilactone, and tellimagrandin [18, 19]. Almost 49 compounds, the majority of which were flavonoids, phenolic acids, and tannins [9, 19-26] isolated from pomegranate peels, are summarized in Figure 1.

The antioxidant activity of the PPEs is attributed to the phenolic acids, flavonoids, and tannins. Among these, ellagitannins are noted to be most responsible for the antioxidant activity of the pomegranate peels [9]. It was also stated that both concentrations of phytochemicals and antioxidant activity are highly dependent upon the solvents used for the peel extraction. Previous studies also suggested that the methanolic extracts of the pomegranate peels exhibit higher antioxidant activity as compared with other extractions methods [27]. The concentrations of phenolic acids, flavonoids, and tannins in PPEs mainly depend on the extraction method. For example, Orak et al. [28] reported the highest concentrations of tannins identified from methanol extracts, as compared with water and ethanol extracts. Acetone extracts of pomegranate peels were also noted to have higher antioxidant activity than the water and ethanol extracts [19].

\section{The Extract Process of Pomegranate Peel}

One of the most widely used methods for pomegranate peel extraction is the methanol extraction method reported by Dahham et al. [29]. In this method, first of all, the fine peel powders are obtained by an electric blender and oven-dried at $40^{\circ} \mathrm{C}$ for $24 \mathrm{~h}$. Then, the powders are sieved through a $24-$ mesh, and $10 \mathrm{~g}$ of powder sample is extracted with $250 \mathrm{ml}$ of $80 \%$ methanol at room temperature $\left(\sim 25^{\circ} \mathrm{C}\right)$ for $24 \mathrm{~h}$. The final extract is then filtered and used. If the aqueous extract is needed for use, the powdered sample $(10 \mathrm{~g})$ is extracted with $100 \mathrm{ml}$ of distilled water and used. The drying temperature and duration was reported as $50^{\circ} \mathrm{C}$ for $48 \mathrm{~h}$ in some other studies [11].

Water, ethanol, and acetone are the other solvents reported to be used instead of methanol for the extraction of the pomegranate peel $[19,28]$. Most of the published literature about the different extraction methods/solvents recommended that the methanol extraction method is better than others in terms of the abundance of phenolic compounds and increase antioxidant activity [28, 30-32].

The extraction method is reported to have a strong influence on the biochemical composition of PPEs. The conventional techniques generally need high amounts of solvents and results with low extraction yields. Moreover, the use of high temperature is reported to result in degradation in the extracts [33]. Recently, high-pressure extraction is observed and noted as a practical methodology, which results with no detrimental effects on bioactive compounds. Additionally, to be a green technology, the high-pressure extraction is faster and has a high yield [34].

Another important extraction method is the enzymatic extraction. It was reported to assist in the extraction of bioactive compounds. The mechanism behind the enzymatic extraction involves some cell wall degrading enzymes (i.e., pectinases). These enzymes break down the cell wall and improve the extraction of the bioactive compounds $[35,36]$.

\section{Antimicrobial Activity of Pomegranate Peel}

Pomegranate has a broad spectrum of antimicrobial effects, which has an apparent inhibitory effect against Gramnegative, Gram-positive bacteria (Table 1), fungi, and mould (Table 2). However, different extracts from different parts of pomegranate have various antimicrobial activities. The study of many scholars showed that the antimicrobial activity of PPE was more potent than other parts, and the antimicrobial activity of PPE was related to the total flavonoids and tannins content. PPE is well known for its antimicrobial activity against bacterial and fungal pathogens [29, 37, 38]. However, the number of studies which investigated the effects of PPE against plant pathogenic bacteria and fungi is limited $[11,32,39,40]$. PPE was noted to have antibacterial effects on different foodborne pathogens including Escherichia coli, Fusarium sambucinum, Penicillium italicum, and Bacillus subtilis $[11,31,38,41]$. In one of these comprehensive studies, the antimicrobial activity of extracts derived from different parts of pomegranates (peel, seeds, juice, and whole fruits) was tested on seven bacteria (Bacillus coagulans, Bacillus cereus, B. subtilis, Staphylococcus aureus, E. coli, Klebsiella pneumoniae, and Pseudomonas aeruginosa). The maximum inhibitory of all bacteria was noted from the peel extracts of pomegranates [29]. Pomegranate peel was also tested as an incorporation agent into bio-based films and was found to improve the antibacterial activity of materials. In one of these studies, Ali et al. [42] reported that PPE inhibited the growth of $S$. aureus (Gram-positive) and Salmonella (Gram-negative). As discussed in Section 3, the extraction method can significantly influence the antimicrobial activity of pomegranate peels. In a recent study, antimicrobial effects of high pressure (300 and $600 \mathrm{MPa})$ of the pomegranate peels were tested by [13]. In this study, the maximum antioxidant activity and phenolic content were observed at the extraction of $300 \mathrm{MPa}$; thus, the higher antimicrobial activity against pathogenic bacteria was noted from $300 \mathrm{MPa}$. The ethyl acetate extract of pomegranate peel was previously reported to include high concentrations of tannins which are very active against Staphylococcus aureus 
<smiles></smiles>

$1 \mathrm{R}_{1}=\mathrm{O}-\beta-\mathrm{D}-\mathrm{Gl} ; \mathrm{R}_{2}=\mathrm{H} ; \mathrm{R}_{3}=\mathrm{H}$ $2 \mathrm{R}_{1}=\mathrm{O}-\beta-\mathrm{D}-\mathrm{Xyl} ; \mathrm{R}_{2}=\mathrm{H} ; \mathrm{R}_{3}=\mathrm{H}$ $3 \mathrm{R}_{1}=\mathrm{O}-\beta$-D-Glc; $\mathrm{R}_{2}=\mathrm{OH} ; \mathrm{R}_{3}=\mathrm{H}$ $5 \mathrm{R}_{1}=\mathrm{O}-\beta$-D-rutinoside; $\mathrm{R}_{2}=\mathrm{H} ; \mathrm{R}_{3}=\mathrm{OC}$ $6 \mathrm{R}_{1}=\mathrm{O}-\beta$-D-Glc; $\mathrm{R}_{2}=\mathrm{H} ; \mathrm{R} 3=\mathrm{OH}$ $7 \mathrm{R}_{1}=\mathrm{H} ; \mathrm{R}_{2}=\mathrm{H} ; \mathrm{R}_{3}=\mathrm{H}$
$8 \mathrm{R}_{1}=\mathrm{H} ; \mathrm{R}_{2}=\mathrm{H} ; \mathrm{R}_{3}=\mathrm{OH}$
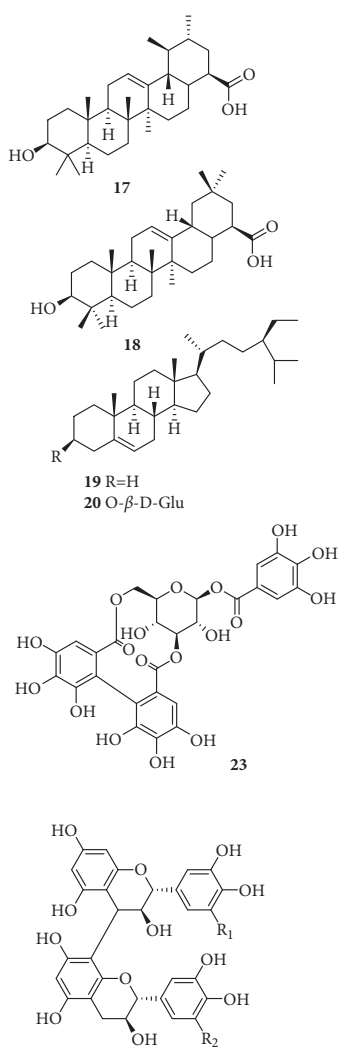

$26 \mathrm{R}_{1}=\mathrm{OH} ; \mathrm{R}_{2}=\mathrm{H}$ $27 \mathrm{R}_{1}=\mathrm{OH} ; \mathrm{R}_{2}=\mathrm{OH}$
$28 \mathrm{R}_{1}=\mathrm{H} ; \mathrm{R}_{2}=\mathrm{OH}$<smiles>Oc1cc(O)c2c(c1)OC(c1ccc(O)c(O)c1)C(OC1(c3ccc(O)c(O)c3)Oc3cc(O)cc(O)c3C(O)C1O)C2</smiles><smiles>O=Cc1ccc(CO)o1</smiles>
$4 \mathrm{R}_{1}=\mathrm{O}-\beta$-D-rutinoside; $\mathrm{R}_{2}=\mathrm{H} ; \mathrm{R}_{3}=$

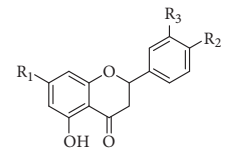

$9 \mathrm{R}_{1}=\mathrm{O}-\beta-\mathrm{D}-\mathrm{Glc} ; \mathrm{R}_{2}=\mathrm{OH} ; \mathrm{R}_{3}=\mathrm{H}$ $10 \mathrm{R}_{1}=\mathrm{OH} ; \mathrm{R}_{2}=\mathrm{O}-\beta$-D-Glu; $\mathrm{R}_{3}=\mathrm{OH}$

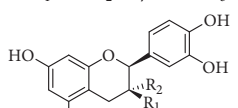

$$
\mathrm{OH}_{\mathrm{R}_{1}}
$$

$11 \mathrm{R}_{1}=\mathrm{H} ; \mathrm{R}_{2}=\mathrm{OH}$ $12 \mathrm{R}_{1}=\mathrm{OH} ; \mathrm{R}_{2}=\mathrm{H}$
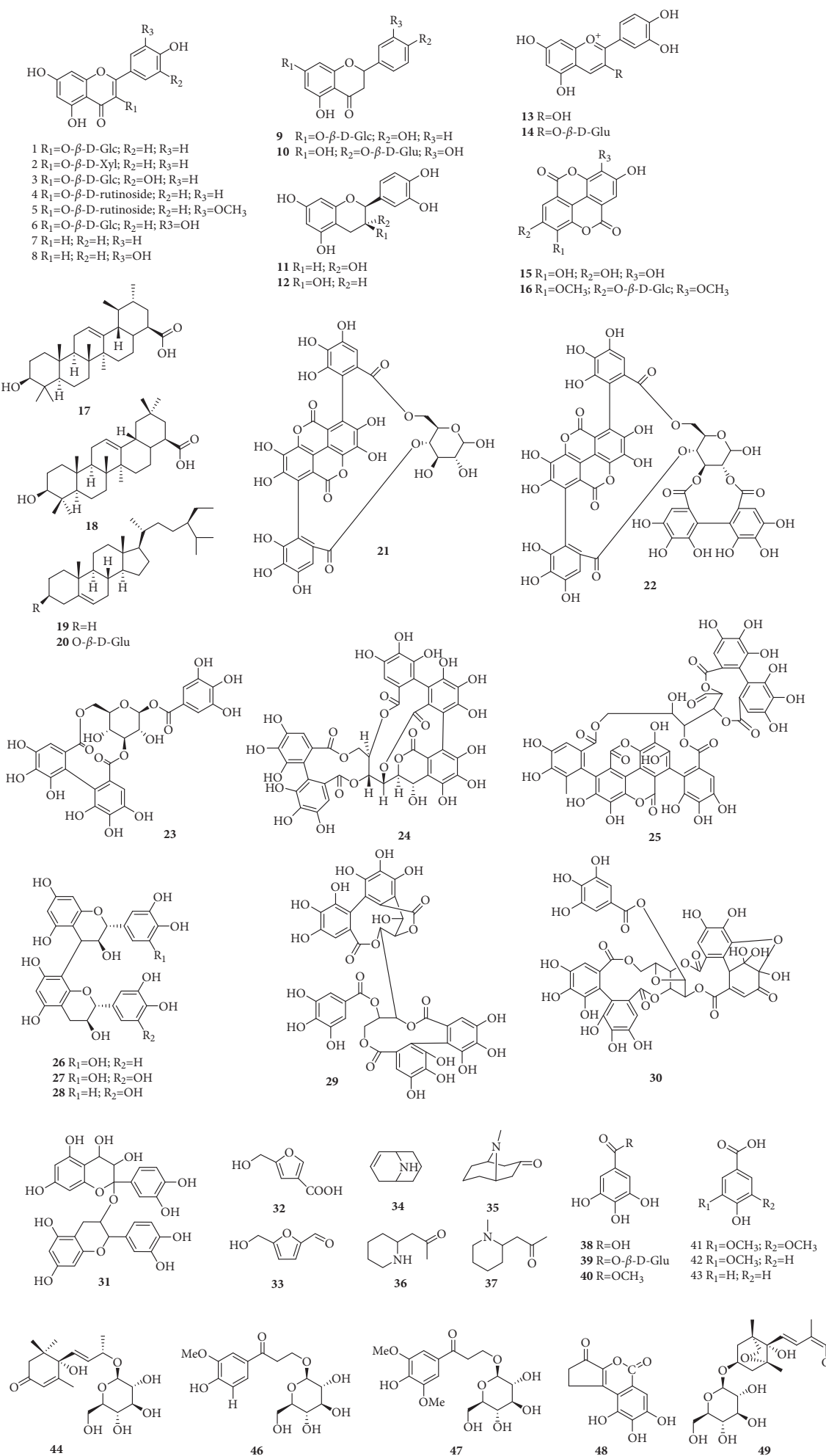

$15 \mathrm{R}_{1}=\mathrm{OH} ; \mathrm{R}_{2}=\mathrm{OH} ; \mathrm{R}_{3}=\mathrm{OH}$ $16 \mathrm{R}_{1}=\mathrm{OCH}_{3} ; \mathrm{R}_{2}=\mathrm{O}-\beta$-D-Glc; $\mathrm{R}_{3}=\mathrm{OCH}_{3}$
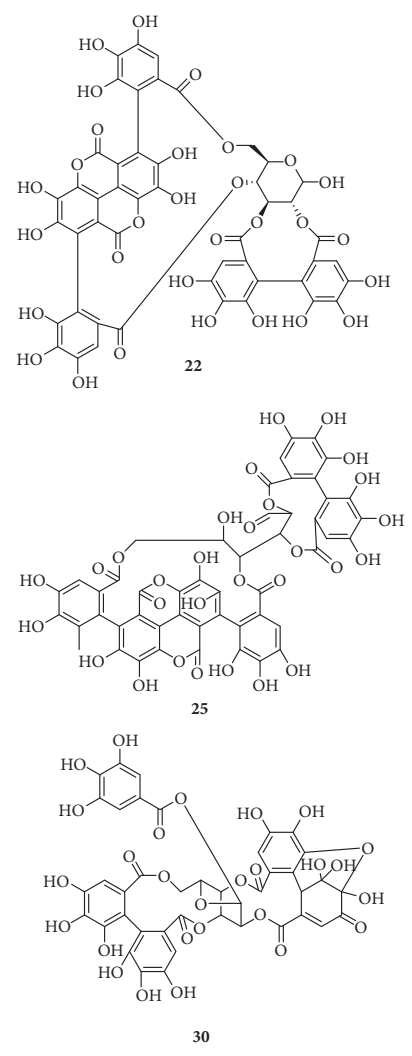

FIGURE 1: Chemical structures of reported compounds from pomegranate peels. strains [43]. Water extract of pomegranate peel was also reported to control Gram-positive significantly and Gramnegative bacteria including E. coli, B. subtilis, Enterobacter aerogenes, Serratia marcescens, Brucella spp., Saccharomyces cerevisiae, and Rhodotorula glutinis [44].
In a different study, the effects of PPEs for controlling the growth and development of Fusarium sambucinum were tested in in vitro as curative and preventive. The researchers noted that the PPE $(20 \mathrm{mg} / \mathrm{ml})$ exhibited complete inhibition of spore germination and $75.5 \%$ 
TABLE 1: Antibacterial effects of pomegranate peel against different pathogens.

\begin{tabular}{|c|c|c|c|}
\hline Bacteria & Peel preparation and dose & Mechanism of action & Reference \\
\hline $\begin{array}{l}\text { Eight different food contaminants/pathogenic } \\
\text { bacteria }\end{array}$ & Under high pressure at $300 \mathrm{MPa}$ & $\begin{array}{l}\text { Due to high antioxidant activity and } \\
\text { high total phenolic content }\end{array}$ & {$[13]$} \\
\hline $\begin{array}{l}\text { B. coagulans, B. cereus, B. subtilis, S. aureus, } \\
\text { E. coli, K. pneumoniae, and } P \text {. aeruginosa }\end{array}$ & $\begin{array}{l}10 \mathrm{~g} \text { sample }(\text { sample }=10 \mathrm{~g} \text { peel } \\
\text { extracted with } 250 \mathrm{ml} 80 \% \text { methanol }) \\
\text { extracted with } 100 \mathrm{~mL} \text { water }\end{array}$ & $\begin{array}{l}\text { Estimated to be a result of high } \\
\text { phytocompounds including phenols, } \\
\text { tannins, and flavonoids. }\end{array}$ & [29] \\
\hline S. aureus and Salmonella & $\begin{array}{c}2,4,6,8,10,12 \text {, and } 14 \% \text { PPE with } \\
20 \% \text { polyethylene glycol }\end{array}$ & $\begin{array}{l}\text { Inhibition of films against targeted } \\
\text { microorganisms }\end{array}$ & {$[42]$} \\
\hline S. aureus & $\begin{array}{l}\text { The ethyl acetate extract of } \\
\text { pomegranate peel }\end{array}$ & $\begin{array}{l}\text { Due to the high concentrations of } \\
\text { tannins }\end{array}$ & [43] \\
\hline
\end{tabular}

Gram-positive and Gram-negative bacteria including E. coli, B. subtilis, E. aerogenes, S. marcescens, Brucella spp., S. cerevisiae, and Water extracts of pomegranate peels $(50 / 100 \mathrm{w} / \mathrm{v})$

Due to high tannins content R. glutinis.

TABLE 2: Antifungal effects of pomegranate peel against different pathogens.

\begin{tabular}{|c|c|c|c|}
\hline Fungi & Peel preparation and dose & Mechanism of action & Reference \\
\hline F. sambucinum & $\begin{array}{l}\text { The methanol extract of pomegranate peels } \\
\qquad\left(20 \mathrm{mg} \cdot \mathrm{ml}^{-1}\right)\end{array}$ & $\begin{array}{l}\text { Due to the high contents of phenolic } \\
\text { compounds }\end{array}$ & {$[11]$} \\
\hline $\begin{array}{l}\text { P. digitatum and Saccharomyces } \\
\text { cerevisiae. }\end{array}$ & $0.061-0.304 \mathrm{~g}$ dry methanolic extract $\mathrm{mL}^{-1}$ & Inhibit cellular receptors of pathogens & {$[32]$} \\
\hline $\begin{array}{l}\text { Brown rot (caused by Monilinia } \\
\text { laxa and } M . \text { fructigena) }\end{array}$ & Aqueous PPEs (9.93 and $12.84 \mathrm{mg} \cdot \mathrm{ml}^{-1}$ ) & $\begin{array}{l}\text { Due to the high total phenolic and } \\
\text { flavonoid contents }\end{array}$ & {$[45]$} \\
\hline $\begin{array}{l}\text { B. cinerea, } P \text {. digitatum, and } \\
\text { P. expansum }\end{array}$ & $20 \mathrm{~h}$ of incubation with PPE $\left(1.2\right.$ and $\left.12 \mathrm{~g} \cdot \mathrm{L}^{-1}\right)$ & $\begin{array}{l}\text { Due to the high concentrations of } \\
\text { ellagitannins }\end{array}$ & {$[46]$} \\
\hline F. oxysporum f. sp. lycopersici & $\begin{array}{l}\text { Water extract }(80 \%) \text {, methanol extract }(40 \%) \text {, and } \\
\text { ethanol extract }(20 \%) \text { of pomegranate peel }\end{array}$ & $\begin{array}{l}\text { Due to the high levels of total phenol } \\
\text { and punicalagin contents. }\end{array}$ & {$[47]$} \\
\hline P. digitatum & $\begin{array}{l}\text { Incorporation of } 0.361 \mathrm{~g} \text { water PPE into locust } \\
\text { bean gum and chitosan coatings }\end{array}$ & $\begin{array}{l}\text { Due to the high contents of phenolic } \\
\text { compounds }\end{array}$ & {$[48]$} \\
\hline
\end{tabular}

inhibition on mycelia growth of fungi [11]. In a recent study, El Khetabi et al. [45] studied the in vitro and in vivo effects of aqueous PPE on the brown rot (caused by Monilinia laxa and M. fructigena). They reported an inhibition varying from $76.65 \%$ to $90 \%$ on the control of mycelia growth. Intense fungicidal activity of PPE was then reported against Botrytis cinerea, Penicillium digitatum, and Penicillium expansum by Nicosia et al. [46]. $20 \mathrm{~h}$ of incubation with PPE resulted with almost complete inhibition of all fungal spores at lemons and grapefruits. A recent study investigated the antifungal activity of 21 different pomegranate genotypes [47]. Researchers noted that all of the tested genotypes have varying antifungal activities, against Fusarium oxysporum f. sp. lycopersici, where some of them completely inhibit the fungus, and some others had deficient inhibitory activity. The two different extracts of pomegranate peel (water and methanol) were incorporated with chitosan and locust bean gum for controlling $P$. digitatum at orange fruits. Results suggested that the addition of $0.361 \mathrm{~g}$ water PPE into both locust bean gum and chitosan coatings significantly reduce the $P$. digitatum by $28 \%$ and $49 \%$, respectively [48]. Phenolic profile and antimicrobial activity of "Gabsi" PPEs were studied by Kharchoufi et al. [32]. Similar to the previous studies of the researchers, the water and methanol solvents were tested separately. Researchers noted different results than their other studies and recommended that the methanol extraction is more effective against the P. digitatum and Saccharomyces cerevisiae.

There are still significant obstacles for the industrial use of PPEs to control postharvest pathogens. This limitation is due to the unclear mode of action of PPE, high costs, lack of curative effect, significant variation among varieties, climatic conditions, cultivation practices, and extraction methods and limited range of activity against different fungal pathogens $[9,49]$.

\section{Biochemical Changes and Food Preservation of Pomegranate Peel}

PPE is a valuable by-product for the food preservation industry. As discussed previously, PPE is a rich source of bioactive compounds, including tannins consisting of ellagic acid and gallic acid [42, 50, 51]. Most of the bioactive compounds, which are abundant in the PPE, were previously tested as natural additives for improving the preservation quality of food [52]. PPE was yet tested alone or in combination with edible films and coatings for food preservation. Renewable, bio-based, environment friendly active packaging systems, which are usually composed of biopolymers such as proteins, lipids, and polysaccharides [53], have been extensively used in food packaging since the 
beginning of the 21st century [54]. Legume seeds as a good source of plant proteins (25-28\%) have a good potential as a bio-based film [55].

Moreover, incorporation of natural compounds (with high contents of antioxidant activity, phenolic compounds, and essential oils) into bio-based films is known to improve the activity of edible coatings and enhance the storage duration of food products [56]. Among these, fruit peels constitute an essential part, which is a rich source of bioactive compounds. PPEs have also been widely used in the formulation of bio-based edible coatings/films [57]. The PPE was also noted to reduce the water vapour permeability of chitosan-based film material and its antimicrobial activity [58]. Another recent study showed that the incorporation of different concentrations of PPE with mung bean protein films provides a biofunctional edible film for packaging of food products [59]. The incorporation of PPE was reported to give flexibility to the films, increase the thickness and water vapour permeability, and decreases the moisture content. It was determined that PPE retains its semicrystalline structure in bio-based edible films and improves the efficacy of the material [42]. In a similar study, incorporation of PPE in chitosan was tested for food packaging [60]. The addition of PPE to active polyvinyl alcohol (PVA) composite film also resulted in high antioxidant activity and antibacterial ability [61].

The incorporation of PPE (1\% w/v) into chitosan (1\% w/ v) and alginate $(2 \% \mathrm{w} / \mathrm{v})$ coatings was then reported to improve the postharvest storability of "Allahabad safeda" guava fruits. Results suggested that the edible coatings reduced the respiration rate, protected ascorbic acid content, total phenolics, total flavonoids content, and antioxidant activity, and maintained the overall fruit quality [62]. The phenolics in foods capture free radicals, produced during oxidative stress, and prevent the deterioration of the foods [63]. Several studies with other edible coatings confirm that the edible coatings reduce the respiration rates and help to maintain the postharvest quality of fresh fruits $[64,65]$. Reduction in respiration rate results with a decrease in the enzyme activity and thereby resulting in a reduction of ascorbic acid oxidation [66] and improves the postharvest storability of foods. Higher respiration rate results in the breakdown of total phenols, and this accelerates the ageing process. Thus, the reduction of the respiration rate by the edible coatings enriched with PPE results with a high amount of phenolic compounds [31] and improved storability of the foods.

Rather than the direct influence on the pathogens, PPEs also induce plant resistant to pathogens. In one of these studies, PPE was reported to cause a transcriptomic response at orange fruits. It was noted that PPE upregulates 273 significant genes and downregulates eight genes. Changes in the gene expressions were noted to enrich antibiotic biosynthesis and induce defence pathways [67].

\section{Prospective}

Pomegranate peel is the waste produced in the process of pomegranate food processing, accounting for $20-30 \%$ of the total weight of pomegranate. The high antioxidant activity, inhibition of lipid peroxidation, and broad-spectrum antimicrobial efficiency of pomegranate peel play an intrinsic quality foundation for its development as a food preservative. To make pomegranate peel more widely used in food preservation, the following aspects need to be further studied and explored:

(1) Study on active antimicrobial components of pomegranate peel. Pomegranate peel composition is complicated. Although the chemical composition of pomegranate peel was well studied, the number of specific studies about the mode of action is relatively few. Thus, the direct causes of antimicrobial activities of pomegranate peel are still unclear, and there are other antimicrobial substances in pomegranate peel, which still need further research.

(2) Study on the antibacterial mechanism of pomegranate peel. Pomegranate peel has an excellent bacteriostatic effect, but the mechanism of its bacteriostatic effect has not been studied intensely. Furthermore, research on the mechanism of bacteriostatic impact will be helpful to promote the application of pomegranate peel in the field of food preservation.

(3) Study on the compatibility of pomegranate peel and other chemical food preservatives. Food preservatives from different sources have a synergistic preservative effect. Studying the optimization of the formula of pomegranate peel and other chemical preservatives can enhance the preservative effect and reduce the amount of chemical preservative.

\section{Data Availability}

The data used to support the findings of this study are included within this article.

\section{Conflicts of Interest}

The authors declare that they have no conflicts of interest.

\section{Acknowledgments}

This research was funded by the Scientific and Technological Research Project of the Department of Education of Jiangxi Province (GJJ180694 and GJJ160360) and Natural Science Foundation in Jiangxi Province (20181BBF60025).

\section{References}

[1] I. Kahramanoglu, "Trends in pomegranate sector: production, postharvest handling and marketing," International Journal of Agriculture Forestry and Life Sciences, vol. 3, no. 2, pp. 239246, 2019.

[2] I. Kahramanoglu and S. Usanmaz, Pomegranate Production and Marketing, CRC Press Taylor \& Francis Group, Boca Raton, FL, USA, 2016.

[3] X. Wu, G. Cao, and R. L. Prior, "Absorption and metabolism of anthocyanins in elderly women after consumption of 
elderberry or blueberry," The Journal of Nutrition, vol. 132, no. 7, pp. 1865-1871, 2002.

[4] V. Sorrenti, C. L. Randazzo, C. Caggia et al., "Beneficial effects of pomegranate peel extract and probiotics on pre-adipocyte differentiation," Frontiers in Microbiology, vol. 10, p. 660, 2019.

[5] D. Surendhiran, C. Li, H. Cui, and L. Lin, "Fabrication of high stability active nanofibers encapsulated with pomegranate peel extract using chitosan/PEO for meat preservation," Food Packaging and Shelf Life, vol. 23, Article ID 100439, 2020.

[6] B. A. Wafa, M. Makni, S. Ammar et al., "Antimicrobial effect of the Tunisian Nana variety Punica granatum L. extracts against Salmonella enterica (serovars Kentucky and Enteritidis) isolated from chicken meat and phenolic composition of its peel extract," International Journal of Food Microbiology, vol. 241, pp. 123-131, 2017.

[7] F. Licciardello, S. Kharchoufi, G. Muratore, and C. Restuccia, "Effect of edible coating combined with pomegranate peel extract on the quality maintenance of white shrimps (Parapenaeus longirostris) during refrigerated storage," Food Packaging and Shelf Life, vol. 17, pp. 114-119, 2018.

[8] Z. Amri, F. Zaouay, H. Lazreg-Aref et al., "Phytochemical content, fatty acids composition and antioxidant potential of different pomegranate parts: comparison between edible and non edible varieties grown in Tunisia," International Journal of Biological Macromolecules, vol. 104, pp. 274-280, 2017.

[9] B. Singh, J. P. Singh, A. Kaur, and N. Singh, "Phenolic compounds as beneficial phytochemicals in pomegranate (Punica granatum L.) peel: a review," Food Chemistry, vol. 261, pp. 75-86, 2018.

[10] W. Elfalleh, N. Tlili, N. Nasri et al., "Antioxidant capacities of phenolic compounds and tocopherols from Tunisian pomegranate (Punica granatum) fruits," Journal of Food Science, vol. 76, no. 5, pp. C707-C713, 2011.

[11] E. A. Elsherbiny, B. H. Amin, and Z. A. Baka, "Efficiency of pomegranate (Punica granatum L.) peels extract as a high potential natural tool towards Fusarium dry rot on potato tubers," Postharvest Biology and Technology, vol. 111, pp. 256-263, 2016.

[12] K. B. Arun, P. Jayamurthy, C. V. Anusha, S. K. Mahesh, and P. Nisha, "Studies on activity guided fractionation of pomegranate peel extracts and its effect on antidiabetic and cardiovascular protection properties," Journal of Food Processing and Preservation, vol. 41, no. 1, p. e13108, 2017.

[13] E. M. C. Alexandre, S. Silva, S. A. O. Santos et al., "Antimicrobial activity of pomegranate peel extracts performed by high pressure and enzymatic assisted extraction," Food Research International, vol. 115, pp. 167-176, 2019.

[14] I. Stojanovic, K. Šavikin, N. Djedovic et al., "Pomegranate peel extract ameliorates autoimmunity in animal models of multiple sclerosis and type 1 diabetes," Journal of Functional Foods, vol. 35, pp. 522-530, 2017.

[15] S. Gözlekçi, O. Saraçoglu, E. Onursal, and M. Özgen, “Total phenolic distribution of juice, peel, and seed extracts of four pomegranate cultivars," Pharmacognosy Magazine, vol. 7, no. 26, pp. 161-164, 2011.

[16] O. A. Fawole, N. P. Makunga, and U. L. Opara, "Antibacterial, antioxidant and tyrosinase-inhibition activities of pomegranate fruit peel methanolic extract," BMC Complementary and Alternative Medicine, vol. 12, no. 1, p. 200, 2012.

[17] X. Zhao, Z. Yuan, Y. Fang, Y. Yin, and L. Feng, "Flavonols and flavones changes in pomegranate (Punica granatum L.) fruit peel during fruit development," Journal of
Agricultural Science and Technology, vol. 16, no. 7, pp. 1649-1659, 2014.

[18] C. Pagliarulo, V. De Vito, G. Picariello et al., "Inhibitory effect of pomegranate (Punica granatum L.) polyphenol extracts on the bacterial growth and survival of clinical isolates of pathogenic Staphylococcus aureus and Escherichia coli," Food Chemistry, vol. 190, pp. 824-831, 2016.

[19] M. Abid, H. Yaich, S. Cheikhrouhou et al., "Antioxidant properties and phenolic profile characterization by LC-MS/ MS of selected Tunisian pomegranate peels," Journal of Food Science and Technology, vol. 54, no. 9, pp. 2890-2901, 2017.

[20] G. W. Plumb, S. de Pascual-Teresa, C. Santos-Buelga, J. C. Rivas-Gonzalo, and G. Williamson, "Antioxidant properties of gallocatechin and prodelphinidins from pomegranate peel," Redox Report, vol. 7, no. 1, pp. 41-46, 2002.

[21] L. Jia, L. Yan, and X. Li-Zhen, "Chemical constituents from leaves of Punica granatum L." Central South Pharmacy, vol. 23, no. 1, pp. 54-57, 2005.

[22] K. Rena, A. Palida, and X. Y. Zhang, "Studies on the chemical constituents from Xinjiang Punica granatum," Journal of Chinese Medicinal Materials, vol. 32, no. 3, pp. 363-365, 2009.

[23] L. Li, C. Wen, Q. Hui-Min, and M. Gui-Zhi, "Chemical compositions of effective part in total polyphenols from pomegranate peel," Chinese Journal of Experimental Traditional Medical Formulae, vol. 22, no. 6, pp. 71-74, 2016.

[24] S. S. Zhao, D. X. Ma, Y. Zhu et al., "Antidiarrheal effect of bioactivity-guided fractions and bioactive components of pomegranate (Punica granatum L.) peels," Neurogastroenterology and Motility, vol. 30, no. 7, p. e13364, 2018.

[25] G. Hairu, Z. Fangjuan, L. Longgen, W. Yuehu, S. Qianyun, and W. Li, "The chemical constituents from Punica granatum peels," Journal of Yunnan Agricultural University (Natural Science), vol. 34, no. 2, pp. 362-369, 2019.

[26] E. Hernández-Corroto, M. L. Marina, and M. C. García, "Extraction and identification by high resolution mass spectrometry of bioactive substances in different extracts obtained from pomegranate peel," Journal of Chromatography A, vol. 1594, no. 7, pp. 82-92, 2019.

[27] A. Kulkarni, S. Aradhya, and S. Divakar, "Isolation and identification of a radical scavenging antioxidant-punicalagin from pith and carpellary membrane of pomegranate fruit," Food Chemistry, vol. 87, no. 4, pp. 551-557, 2004.

[28] H. H. Orak, H. Yagar, and S. S. Isbilir, "Comparison of antioxidant activities of juice, peel, and seed of pomegranate (Punica granatum L.) and inter-relationships with total phenolic, tannin, anthocyanin, and flavonoid contents," Food Science and Biotechnology, vol. 21, no. 2, pp. 373-387, 2012.

[29] S. S. Dahham, M. N. Ali, H. Tabassum, and M. Khan, "Studies on antibacterial and antifungal activity of pomegranate (Punica granatum L.)," American-Eurasian Journal of Agricultural \& Environmental Sciences, vol. 9, no. 3, pp. 273-281, 2010.

[30] M. Çam and Y. Hışıl, "Pressurised water extraction of polyphenols from pomegranate peels," Food Chemistry, vol. 123 , no. 3 , pp. $878-885,2010$.

[31] A. Tehranifar, Y. Selahvarzi, M. Kharrazi, and V. J. Bakhsh, "High potential of agro-industrial by-products of pomegranate (Punica granatum L.) as the powerful antifungal and antioxidant substances," Industrial Crops And Products, vol. 34, no. 3, pp. 1523-1527, 2011.

[32] S. Kharchoufi, F. Licciardello, L. Siracusa, G. Muratore, M. Hamdi, and C. Restuccia, "Antimicrobial and antioxidant 
features of "Gabsi" pomegranate peel extracts," Industrial Crops and Products, vol. 111, pp. 345-352, 2018.

[33] E. M. C. Alexandre, L. M. G. Castro, S. A. Moreira, M. Pintado, and J. A. Saraiva, "Comparison of emerging technologies to extract high-added value compounds from fruit residues: pressure-and electro-based technologies," Food Engineering Reviews, vol. 9, no. 3, pp. 190-212, 2017.

[34] H.-W. Huang, C.-P. Hsu, B. B. Yang, and C.-Y. Wang, "Advances in the extraction of natural ingredients by high pressure extraction technology," Trends in Food Science o Technology, vol. 33, no. 1, pp. 54-62, 2013.

[35] B. B. Li, B. Smith, and M. M. Hossain, "Extraction of phenolics from citrus peels: II. Enzyme-assisted extraction method," Separation and Purification Technology, vol. 48, no. 2, pp. 189-196, 2013.

[36] X. Zhai, C. Zhu, Y. Li, Y. Zhang, Z. Duan, and X. Yang, "Optimization for pectinase-assisted extraction of polysaccharides from pomegranate peel with chemical composition and antioxidant activity," International Journal of Biological Macromolecules, vol. 109, pp. 244-253, 2018.

[37] R. Casquete, S. M. Castro, A. Martín et al., "Evaluation of the effect of high pressure on total phenolic content, antioxidant and antimicrobial activity of citrus peels," Innovative Food Science \& Emerging Technologies, vol. 31, pp. 37-44, 2015.

[38] T. Ismail, S. Akhtar, P. Sestili, M. Riaz, A. Ismail, and R. G. Labbe, "Antioxidant, antimicrobial and urease inhibitory activities of phenolics-rich pomegranate peel hydro-alcoholic extracts," Journal of Food Biochemistry, vol. 40, no. 4, pp. 550-558, 2016.

[39] E. H. Endo, D. A. Garcia Cortez, T. Ueda-Nakamura, C. V. Nakamura, and B. P. Dias Filho, "Potent antifungal activity of extracts and pure compound isolated from pomegranate peels and synergism with fluconazole against Candida albicans," Research in Microbiology, vol. 161, no. 7, pp. 534-540, 2010.

[40] F. Romeo, G. Ballistreri, S. Fabroni et al., "Chemical characterization of different sumac and pomegranate extracts effective against Botrytis cinerea rots," Molecules, vol. 20, no. 7, pp. 11941-11958, 2015.

[41] A. Aguilera-Carbo, C. Augur, L. A. Prado-Barragan, E. FavelaTorres, and C. N. Aguilar, "Microbial production of ellagic acid and biodegradation of ellagitannins," Applied Microbiology And Biotechnology, vol. 78, no. 2, pp. 189-199, 2008.

[42] A. Ali, Y. Chen, H. Liu et al., "Starch-based antimicrobial films functionalized by pomegranate peel," International Journal of Biological Macromolecules, vol. 129, pp. 1120-1126, 2019.

[43] T. D. B. Machado, I. C. R. Leal, A. C. F. Amaral, K. R. N. D. Santos, M. G. D. Silva, and R. M. Kuster, "Antimicrobial ellagitannin of Punica granatum fruits," Journal of the Brazilian Chemical Society, vol. 13, no. 5, p. 708, 2002.

[44] H. M. Yehia, M. F. Elkhadragy, and A. E. Moneim, "Antimicrobial activity of pomegranate rind peel extracts," African Journal of Microbiology Research, vol. 4, no. 22, pp. 36643668, 2011.

[45] A. El Khetabi, R. Lahlali, L. Askarne et al., "Efficacy assessment of pomegranate peel aqueous extract for brown rot (Monilinia spp.) disease control," Physiological and Molecular Plant Pathology, vol. 110, p. 101482, 2020.

[46] M. G. L. D. Nicosia, S. Pangallo, G. Raphael et al., "Control of postharvest fungal rots on citrus fruit and sweet cherries using a pomegranate peel extract," Postharvest Biology and Technology, vol. 114, pp. 54-61, 2016.

[47] D. Rongai, P. Pulcini, G. Di Lernia, P. Nota, P. Preka, and F. Milano, "Punicalagin content and antifungal activity of different pomegranate (Punica ganatum L.) genotypes," Horticulturae, vol. 5, no. 3, p. 52, 2019.

[48] S. Kharchoufi, L. Parafati, F. Licciardello et al., "Edible coatings incorporating pomegranate peel extract and biocontrol yeast to reduce Penicillium digitatum postharvest decay of oranges," Food Microbiology, vol. 74, pp. 107-112, 2018.

[49] S. Bautista-Banos, D. Sivakumar, A. Bello-Perez, R. Villanueva-Arce, and M. Hernandez-Lopez, "A review of the management alternatives for controlling fungi on papaya fruit during the postharvest supply chain," Crop Protection, vol. 49, p. 8e20, 2013.

[50] K. Kaderides, L. Papaoikonomou, M. Serafim, and A. M. Goula, "Microwave-assisted extraction of phenolics from pomegranate peels: optimization, kinetics, and comparison with ultrasounds extraction," Chemical Engineering and Processing-Process Intensification, vol. 137, pp. 1-11, 2019.

[51] L.-F. Zhu, X. Chen, Z. Ahmad, J.-S. Li, and M.-W. Chang, "Engineering of Ganoderma lucidum polysaccharide loaded polyvinyl alcohol nanofibers for biopharmaceutical delivery," Journal of Drug Delivery Science and Technology, vol. 50, pp. 208-216, 2019.

[52] S. Munir, Y. Hu, Y. Liu, and S. Xiong, "Enhanced properties of silver carp surimi-based edible films incorporated with pomegranate peel and grape seed extracts under acidic condition," Food Packaging and Shelf Life, vol. 19, pp. 114120, 2019.

[53] N. Fathi, H. Almasi, and M. K. Pirouzifard, "Sesame protein isolate based bionanocomposite films incorporated with $\mathrm{TiO}_{2}$ nanoparticles: study on morphological, physical and photocatalytic properties," Polymer Testing, vol. 77, p. 105919, 2019.

[54] Z. Emam-Djomeh, A. Moghaddam, and S. A. Yasini Ardakani, "Antimicrobial activity of pomegranate (Punica granatum L.) peel extract, physical, mechanical, barrier and antimicrobial properties of pomegranate peel extract-incorporated sodium caseinate film and application in packaging for ground beef," Packaging Technology and Science, vol. 28, no. 10, pp. 869-881, 2015.

[55] S. E. Ebrahimi, A. Koocheki, E. Milani, and M. Mohebbi, "Interactions between Lepidium perfoliatum seed gum-grass pea (Lathyrus sativus) protein isolate in composite biodegradable film," Food Hydrocolloids, vol. 54, pp. 302-314, 2016.

[56] O. Abdelhedi, R. Nasri, M. Jridi et al., "Composite bioactive films based on smooth-hound viscera proteins and gelatin: physicochemical characterization and antioxidant properties," Food Hydrocolloids, vol. 74, pp. 176-186, 2018.

[57] Z. A. N. Hanani, F. C. Yee, and M. A. R. Nor-Khaizura, "Effect of pomegranate (Punica granatum L.) peel powder on the antioxidant and antimicrobial properties of fish gelatin films as active packaging," Food Hydrocolloids, vol. 89, pp. 253-259, 2019.

[58] G. Yuan, H. Lv, B. Yang, X. Chen, and H. Sun, "Physical properties, antioxidant and antimicrobial activity of chitosan films containing carvacrol and pomegranate peel extract," Molecules, vol. 20, no. 6, pp. 11034-11045, 2015.

[59] M. Moghadam, M. Salami, M. Mohammadian, M. Khodadadi, and Z. Emam-Djomeh, "Development of antioxidant edible films based on mung bean protein enriched with pomegranate peel," Food Hydrocolloids, vol. 104, p. 105735, 2020.

[60] H. Cui, D. Surendhiran, C. Li, and L. Lin, "Biodegradable zein active film containing chitosan nanoparticle encapsulated with pomegranate peel extract for food packaging," Food Packaging and Shelf Life, vol. 24, Article ID 100511, 2020. 
[61] L. He, W. Lan, S. Ahmed, W. Qin, and Y. Liu, "Electrospun polyvinyl alcohol film containing pomegranate peel extract and sodium dehydroacetate for use as food packaging," Food Packaging and Shelf Life, vol. 22, Article ID 100390, 2019.

[62] M. S. Nair, A. Saxena, and C. Kaur, "Effect of chitosan and alginate based coatings enriched with pomegranate peel extract to extend the postharvest quality of guava (Psidium guajava L.)," Food Chemistry, vol. 240, pp. 245-252, 2018.

[63] G. Peretto, W.-X. Du, R. J. Avena-Bustillos, J. D. J. Berrios, P. Sambo, and T. H. Mchugh, "Electrostatic and conventional spraying of alginate-based edible coating with natural antimicrobials for preserving fresh strawberry quality," Food and Bioprocess Technology, vol. 10, no. 1, pp. 165-174, 2017.

[64] C. Chen, X. Peng, R. Zeng, M. Chen, C. Wan, and J. Chen, "Ficus hirta fruits extract incorporated into an alginate-based edible coating for Nanfeng Mandarin preservation," Scientia Horticulturae, vol. 202, pp. 41-48, 2016.

[65] S. K. G. Ali, F. Badii, M. Hashemi, A. Y. Ardakani, N. Maftoonazad, and A. M. Gorji, "Effect of nanochitosan based coating on climacteric behavior and postharvest shelflife extension of apple cv. Golab Kohanz," LWT-food Science and Technology, vol. 70, pp. 33-40, 2016.

[66] S. Y. Wang and H. Gao, "Effect of chitosan-based edible coating on antioxidants, antioxidant enzyme system, and postharvest fruit quality of strawberries (Fragaria x Aranassa Duch.)," LWT-Food Science and Technology, vol. 52, no. 2, pp. 71-79, 2013.

[67] I. Belgacem, S. Pangallo, A. Abdelfattah et al., "Transcriptomic analysis of orange fruit treated with pomegranate peel extract (PGE)," Plants, vol. 8, no. 4, p. 101, 2019. 